\title{
CHANGES IN THE PHOSPHATE COMPOUNDS OF THE HUMAN RED BLOOD CELL DURING BLOOD BANK STORAGE*
}

\author{
BY GRANT R. BARTLETT AND HARRY N. BARNET $\dagger$ \\ (From the Scripps Clinic and Research Foundation, La Jolla, Calif., and The San Diego Blood \\ Bank, San Diego, Calif.)
}

(Submitted for publication June 8, 1959; accepted September 10, 1959)

The normal human red blood cell, when withdrawn from the circulation, contains a substantial pool of water-soluble organic phosphate compounds, most of which are metabolic intermediates whose concentrations are maintained at constant levels by the glucose metabolism of the cell (1). If blood is stored under blood bank conditions in acid citrate dextrose (ACD) preservative, the organic phosphates of the red cell gradually disappear and inorganic phosphate accumulates. The decline of the organic phosphates coincides with a general deterioration of the cell, for example with a decrease in the glycolytic rate, an inability to concentrate potassium ions and a loss of viability measured by post-transfusion survival (2-4). Several observations have been made previously on the individual phosphate compounds during the storage of human blood in ACD (5-8). In the present study advantage is taken of the high resolution capacity of column chromatography on ion-exchange resins to obtain more complete quantitative information about the nature and changes of the phosphorylated intermediates of red cell metabolism.

\section{METHODS}

Units of blood were obtained from routine collections at the San Diego Blood Bank using glass bottles containing Formula B (National Institutes of Health) ACD, and were stored at $4^{\circ}$ to $6^{\circ} \mathrm{C}$. Seventy-five ml. aliquots were removed from the bottles aseptically at approximately weekly intervals for analysis of the red cells by ionexchange chromatography. No evidence of bacterial contamination was found in the blood at the end of the storage period.

The aliquot of blood was centrifuged, the buffy coat removed and the packed red cells suspended in normal saline and recentrifuged. The washed cells were ex-

* Supported in part by the U. S. Army Medical Research and Development Command, Office of the Surgeon General.

$\dagger$ Present address : California Western University, San Diego, Calif. tracted with trichloroacetic acid and the acid was removed with ether. The extract was passed through a $1 \times 12 \mathrm{~cm}$. column of Dowex $1-\times 8$ chloride (100 to 200 mesh) which was eluted at $2 \mathrm{ml}$. per minute with hydrochloric acid and ammonium chloride eluants as indicated in the figures. Fractions of approximately $20 \mathrm{ml}$. were collected and each was assayed for optical density at $260 \mathrm{~m} \mu$ and for total phosphorus (9). Spectral measurements at the ultraviolet absorbing peaks indicated that most of the material was adenylate. The anthrone (10), carbazole (11) and orcinol (12) reactions were carried out on all fractions of the $0.01 \mathrm{~N} \mathrm{HCl}$ and $0.1 \mathrm{~N}$ $\mathrm{NH}_{4} \mathrm{Cl}$ elution sections to determine the content of sugar mono- and diphosphates. Inorganic phosphate was measured (13) in the $0.01 \mathrm{~N} \mathrm{HCl}$ fractions. Further details of the procedures used for the isolation and extraction of the red cells, for ion-exchange chromatography and for the identification of the phosphate compounds are given elsewhere $(1,14)$.

\section{RESULTS AND DISCUSSION}

Analyses were carried out simultaneously on three units of blood from unselected donors at the blood bank (two male and one female, ages 21 to 32) with normal blood cell counts. The three samples of blood were assayed at $0,8,15,22,33$, 44 and 62 days of storage. The results did not vary by more than 15 per cent and one was selected for presentation of the data. The 0,15 and 62 day chromatographic patterns are shown in Figures 1 through 3 . Figure 4 summarizes the changes observed in the phosphate compounds studied as a function of time.

The zero time assays revealed several marked differences between the cells collected in ACD in the present study and those red cells collected in heparin anticoagulant (1). Apparently a rapid displacement of the normal equilibrium followed shortly after the blood was mixed with the ACD solution. Actually "zero time" refers to two to three hours of in vitro life for the red cell, mostly at reduced temperature, including the period required for the washing and centrifugation of the 


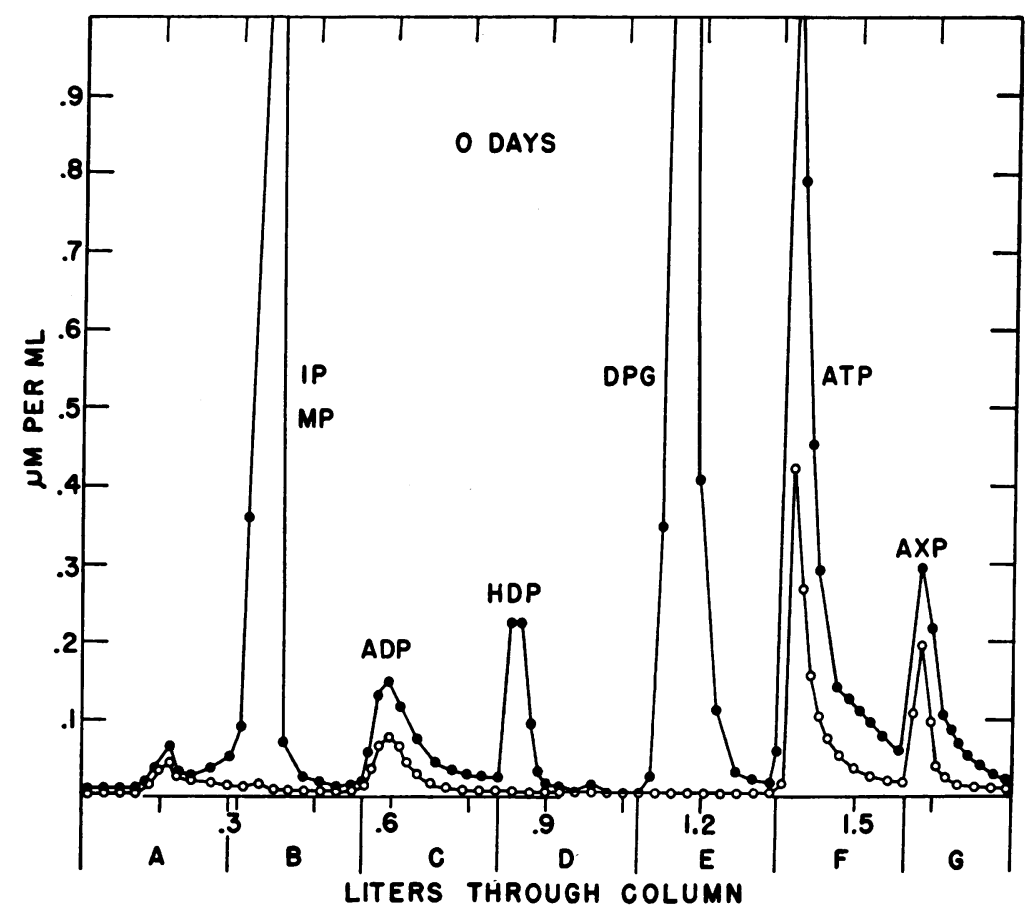

Fig. 1. Ion-Exchange Separation of Red Cell Phosphate Compounds; Zero Days' Storage

The red cell extract was passed through a $1 \times 12 \mathrm{~cm}$. column of Dowex 1- $\times 8$ chloride (100 to 200 mesh) which was eluted at $2 \mathrm{ml}$. per minute with: A, $0.003 \mathrm{~N} \mathrm{HCl} ; \mathbf{B}, 0.01 \mathrm{~N} \mathrm{HCl} ; \mathbf{C}, 0.02 \mathrm{~N} \mathrm{HCl} ; \mathrm{D}, 0.1 \mathrm{~N} \mathrm{NH} . \mathrm{Cl}$; E, $0.2 \mathrm{~N} \mathrm{NH}_{4} \mathrm{Cl} ; \mathbf{F}, 0.5 \mathrm{~N} \mathrm{NH}_{4} \mathrm{Cl} ; \mathrm{G}, 1.0 \mathrm{~N} \mathrm{HCl}$. The data are plotted as $\mu$ Moles per milliliter of eluate and refer to: total phosphorus, $\bullet$; and adenine (from the optical density of $260 \mathrm{~m} \mu, E=15 \times 10^{2}$ ), $O$. The peak values at volumes of $361,378,1,144,1,162$ and $1,181 \mathrm{ml}$. were, respectively, $1.1,1.0,2.3,2.9,2.1$ and $1.3 \mu$ Moles phosphorus per ml. of eluate.

Abbreviations: IP, inorganic phosphate; MP, monophosphates (difference between IP and total phosphorus in the $\mathbf{A}$ and $\mathbf{B}$ elution sections); $\mathrm{ADP}$, adenosine diphosphate; HDP, hexose diphosphate; DPG, 2,3-diphosphoglycerate: ATP, adenosine triphosphate; AXP, unidentified nucleotide.

cells, and so would allow some opportunity for metabolic changes.

The concentrations of both adenosine triphosphate (ATP) and 2,3-diphosphoglycerate (DPG) were slightly lower than normal at zero time and presumably their rapid initial breakdown accounted for most of the extra inorganic phosphate which was about three times higher than normal.

A striking immediate change was the disappearance of fructose diphosphate. It had been found that the hexose diphosphate fraction of the normal human red cell consisted of a mixture of glucose and fructose diphosphates in a ratio of about two to one (1). This was remarkable in that glucose diphosphate does not appear to be present in other tissue in more than trace quantities. That the glucose diphosphate was an active intermediate of glycolysis in the human red cell was demonstrated by its rapid turnover in isotope labeling experiments with carbon ${ }^{14}$ and phosphorus $^{32}$ (15). In contrast to red cells collected in heparin, the hexose diphosphate of the ACD cells contained no fructose diphosphate at zero time as shown by negative carbazole reaction. The cells, however, had an approximately normal amount of glucose diphosphate, identified by chromatographic position and anthrone and phosphorus ratios.

These relatively rapid changes in the red cell which follow shortly after the addition of blood to 


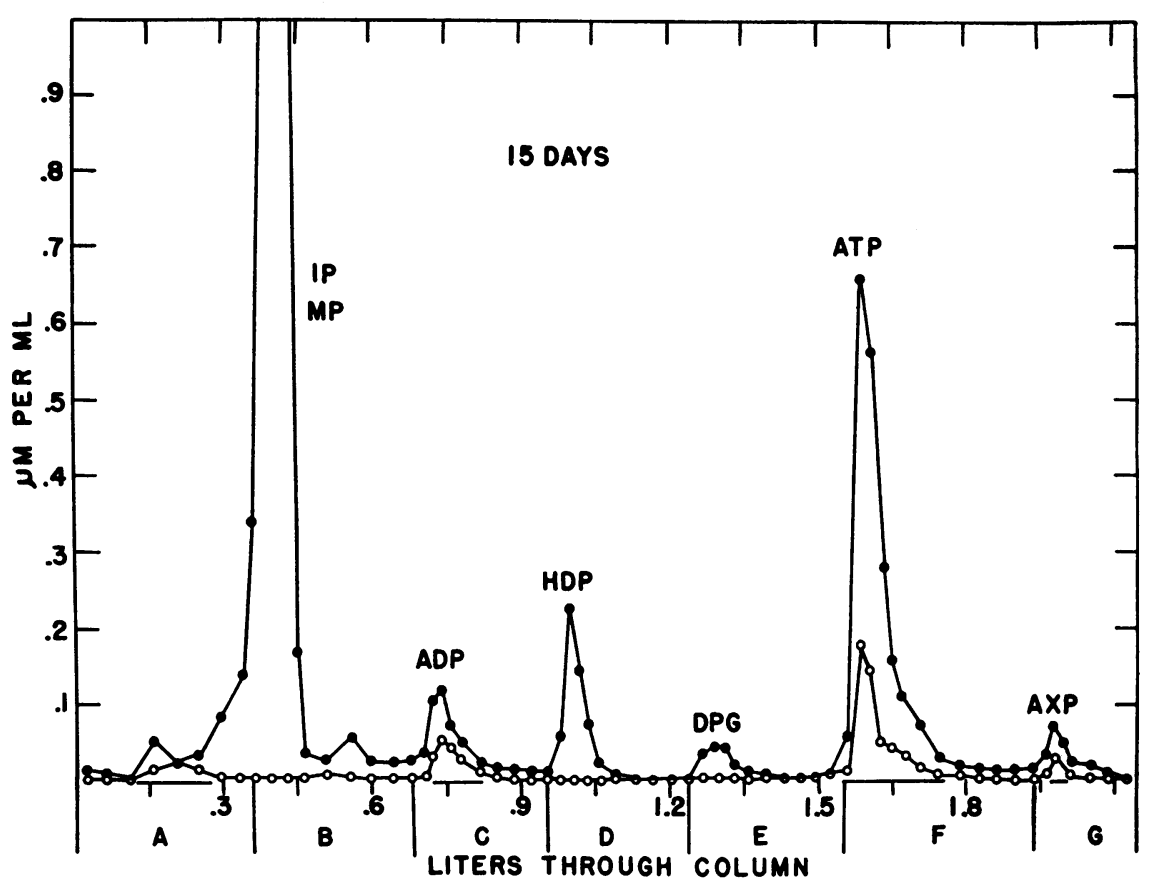

Fig. 2. Ion-Exchange Separation of Red Cell. Phosphate Compounds; 15 Days' Storage

See Figure 1. The peak values at volumes of 388,410 and $433 \mathrm{ml}$. were, respectively, 1.1, 2.2 and $2.7 \mu$ Moles phosphorus per ml. of eluate.

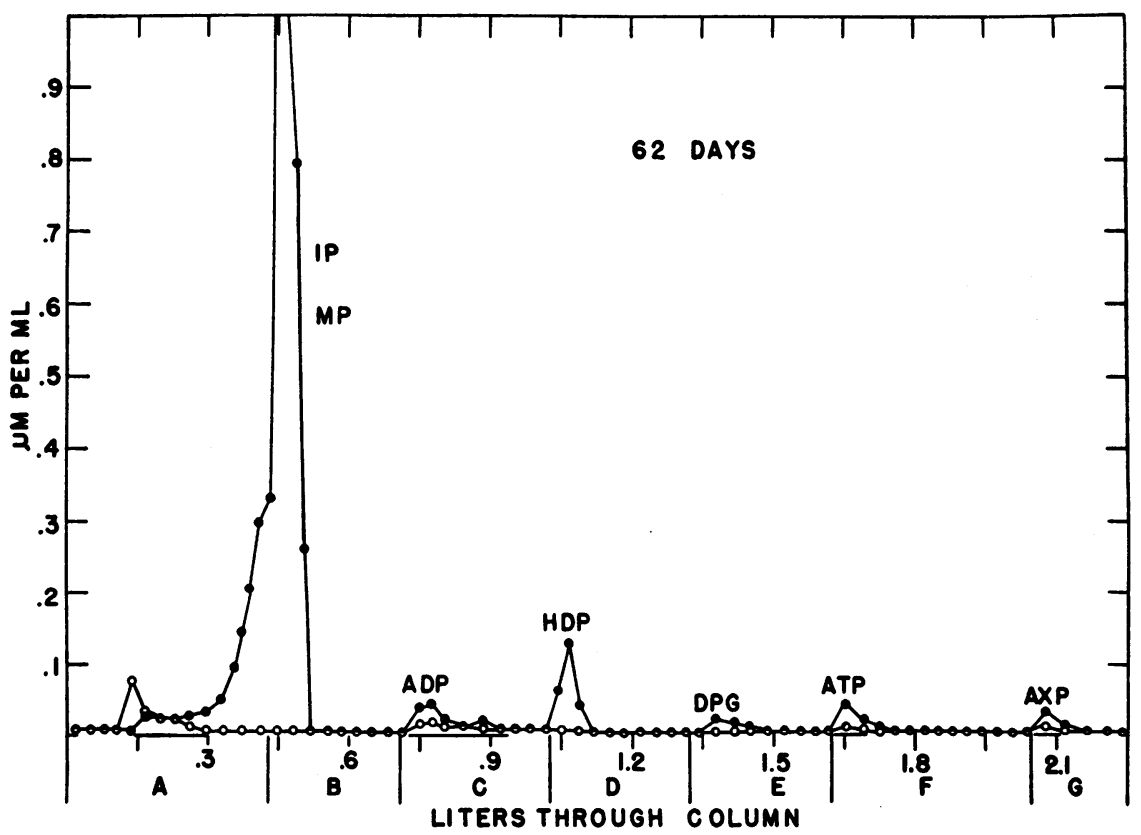

Fig. 3. Ion-Exchange Separation of Red Cell Phosphate Compounds; 62 Days' Storage

See Figure 1. The peak values at volumes of 452 and $472 \mathrm{ml}$. were, respectively, 1.5 and $3.0 \mu$ Moles phosphorus per $\mathrm{ml}$. of eluate. 


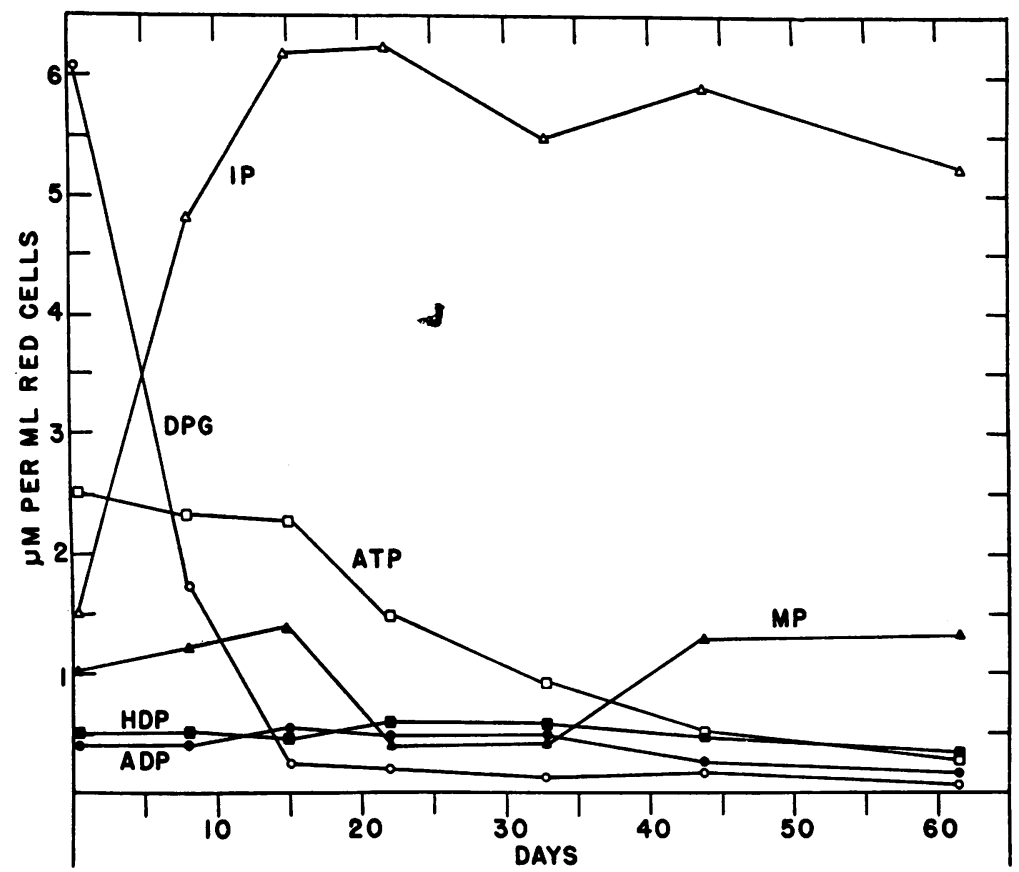

Fig. 4. Summary: Changes of Red Cell Phosphate Compounds during Storage in ACD AT $4^{\circ}$ to $6^{\circ} \mathrm{C}$.

The data are taken from ion-exchange chromatographic separations at $0,8,15,22,33,44$ and 62 days of storage and are plotted as micromoles of phosphorus per milliliter of red cells.

the ACD solution might represent a readjustment of the metabolic equilibrium pattern to the lowered $\mathrm{pH}$ rather than reflecting any damage to the metabolic system.

After 62 days of storage, more than 90 per cent of the trichloroacetic acid extractable organic phosphorus had disappeared from the red cell; of special interest was the variable rate of change of the individual compounds.

The precipitous fall in the concentration of DPG during the first 15 days indicated a rapid change of some part of the metabolic machinery. The ATP content decreased slowly during the same period and then fell more rapidly after the DPG had reached a very low level. If the formation of 1,3-diphosphoglycerate were to slow down because of some defect higher in the chain of reactions, then the synthesis of ATP by the transfer of phosphorus from 1,3-diphosphoglycerate to adenosine diphosphate (ADP) would be decreased as would also ATP generation from phosphopyruvate derived from the monophosphoglycerate part of the 1,3-diphosphoglycerate. If monophospho- glycerate is no longer feeding into the phosphoglycericmutase enzyme reaction, a mechanism could be postulated for activating DPG phosphatase to produce 2-monophosphoglycerate and phosphopyruvate and consequent ATP formation, as long as the supply of DPG held out. Assuming a constant rate of controlled metabolic utilization of ATP by the red cell, its net loss would be accelerated when synthesis from DPG stops.

The sudden loss of fructose diphosphate at the beginning of the storage is difficult to evaluate. Maintenance of a stable level of glucose diphosphate throughout most of the storage might result from the absence of an active mechanism for degrading this compound. It should be pointed out that enzymes outside of the main glycolytic pathway must be brought into action to obtain any net synthesis or breakdown of either glucose diphosphate or DPG.

It would be helpful to know more about the concentrations of glucose-6-phosphate and fructose-6-phosphate during the storage period. The organic phosphate in the weakly acidic ester area 
(0.01 $\mathrm{N} \mathrm{HCl}$ elution section) of the chromatograph was variable and relatively high throughout the storage. This section would include the glucose, fructose and ribose monophosphates. Although positive sugar color tests were obtained it is difficult to characterize and quantify these substances without the use of larger aliquots of red cells and formate rechromatography. Further experiments must be performed before anything definite can be said about the components of this fraction.

The intracellular inorganic phosphate rose rapidly to very high levels and at 15 days was probably derived chiefly from the decomposition of the DPG. The concentration of inorganic phosphate inside of the cell leveled off after 15 days even though considerable breakdown of organic phosphate continued, suggesting that the intracellular saturation point had been reached.

The phosphorus-containing material which was eluted with $1.0 \mathrm{~N} \mathrm{HCl}$, and labeled AXP (adenine spectrum) in the figures, included, in the zero and eight day analyses, some ATP which had not been completely removed from the column with $0.5 \mathrm{~N}$ $\mathrm{NH}_{4} \mathrm{Cl}$. However, there was also present at these times and at the later assays a nucleotide-like substance which has not been identified. Recent studies indicate that a small amount of guanosine triphosphate might be found in this area $(16,17)$.

It would be premature to interpret the observed changes in terms of any specific metabolic block. Present knowledge of carbohydrate metabolism is very extensive in respect to the nature of the individual enzymatic reactions but is exceedingly limited as to how these reactions are integrated into the delicately controlled metabolic processes within the living cell. Eventually the changes of the metabolic intermediates in such abnormal states as that of blood storage should prove to be a sensitive indicator of the metabolic pathology. However, much more must be learned about what determines the intermediate concentrations in the normal steady state and how they will change under various experimental modifications.

\section{SUM MARY}

Phosphorylated metabolic intermediates of the red cell have been assayed by column chromatog- raphy on ion-exchange resin at intervals during 62 days of storage of human blood in acid citrate dextrose $(\mathrm{ACD})$ at $4^{\circ} \mathrm{C}$. There was a rapid loss of fructose diphosphate and a reduction of adenosine triphosphate and 2,3-diphosphoglycerate on mixing blood with ACD solution with a corresponding increase in intracellular inorganic phosphate. Almost all of the 2,3-diphosphoglycerate disappeared from the red cell during the first two weeks. The adenosine triphosphate concentration fell slowly during the same period and then more rapidly with a much slower loss of adenosine diphosphate. The glucose diphosphate level remained fairly constant throughout the incubation. Intracellular inorganic phosphate rose to a very high level at two weeks with no further rise. Some factors which might influence these changes have been discussed.

\section{REFERENCES}

1. Bartlett, G. R. Human red cell glycolytic intermediates. J. biol. Chem. 1959, 234, 449.

2. Rapoport, S. Dimensional, osmotic, and chemical changes of erythrocytes in stored blood. I. Blood preserved in sodium citrate, neutral, and acid citrate-glucose (ACD) mixtures. J. clin. Invest. 1947, 26, 591.

3. Ross, J. F., Finch, C. A., Peacock, W. C., and Sammons, M. E. The in vitro preservation and posttransfusion survival of stored blood. J. clin. Invest. 1947, 26, 687.

4. Gibson, J. G., 2nd, Evans, R. D., Aub, J. C., Sack, T., and Peacock, W. C. The post-transfusion survival of preserved human erythrocytes stored as whole blood or in resuspension, after removal of plasma, by means of two isotopes of radioactive iron. J. clin. Invest. 1947, 26, 715.

5. Gabrio, B. W., and Finch, C. A. Erythrocyte preservation. I. The relation of the storage lesion to in vivo erythrocyte senescence. $\mathrm{J}$. clin. Invest. 1954, 33, 242.

6. Gabrio, B. W., Finch, C. A., and Huennekens, F. M., Erythrocyte preservation: A topic in molecular biochemistry. Blood 1956, 11, 103.

7. Prankerd, T. A. J. Chemical changes in stored blood, with observations on the effects of adenosine. Biochem. J. 1956, 64, 209.

8. Rubenstein, D., Kashket, S., and Denstedt, O. F. Studies on the preservation of blood. IV. The influence of adenosine on the glycolytic activity of the erythrocyte during storage at $4^{\circ} \mathrm{C}$. Canad. J. Biochem. 1956, 34, 61. 
9. Bartlett, G. R. Phosphorus assay in column chromatography. J. biol. Chem. 1959, 234, 466.

10. Dreywood, R. Qualitative test for carbohydrate material. Industr. engin. Chem., Analyt. ed., 1946, 18, 499.

11. Dische, Z., and Borenfreund, E. A new spectrophotometric method for the detection and determination of keto sugars and trioses. J. biol. Chem. 1951, 192, 583.

12. Mejbaum, W. Uber die Bestimmung kleiner Pentosemengen, insbesondere in Derivaten der Adenylsäure. Z. physiol. Chem. 1939, 258, 117.

13. Fiske, C. H., and Subbarow, Y. The colorimetric determination of phosphorus. J. biol. Chem. 1925, 66, 375.

14. Bartlett, G. R. Methods for the isolation of glycolytic intermediates by column chromatography with ion-exchange resins. J. biol. Chem. 1959, 234, 459.

15. Bartlett, G. R. Unpublished data.

16. Bishop, C., Rankine, D. M., and Talbott, J. H. The nucleotides in normal human blood. J. biol. Chem. 1959, 234, 1233.

17. Lowy, B. A., and King, M. Biosynthesis of adenosine triphosphate and guanosine triphosphate in the rabbit erythrocyte in vitro. Fed. Proc. 1959, 18, 277. 